\title{
Design patterns of communication messages for promoting software products on the corporate market ${ }^{1}$
}

\author{
Yuriy P. Yekhlakov \\ Professor, Head of Department of Data Processing Automation \\ Tomsk State University of Control Systems and Radioelectronics \\ Address: 40, Prospect Lenina, Tomsk, 634050, Russian Federation \\ E-mail: upe@tusur.ru
}

\section{Elena K. Malakhovskaya}

Assistant Professor, Department of Data Processing Automation

Tomsk State University of Control Systems and Radioelectronics

Address: 40, Prospect Lenina, Tomsk, 634050, Russian Federation

E-mail:elena_tusur@mail.ru

\begin{abstract}
On the basis of conditions of low-budget software product promotion on the market, applied aspects of semiotics, methods of artificial intelligence and the results of practical experience of advertising agencies with Internet advertising for promotion on the corporate market of goods and services, this article proposes a method for developing design pattern for creating the content of communication messages (CM). The article presents a semantic network which describes the model for developing CM design patterns. It identifies key network concepts: the software product, consumer properties, positioning strategy, potential consumers, consumer preferences, features of information perception, a unique proposal, message distribution tools. Associative links between concepts are described. Elements of a semantic network dictionary are offered: the object of definitions, the characteristics of objects, the semantic units of characteristics; semantic unit description of lexical construction dictionary elements - target, key, alternative. Target lexical constructions describe and specify the format of the advertising message in the template. Key lexical constructions determine unique characteristics of the objects' concept. Alternative lexical constructions are designed to strengthen the influence of semantic units and to exert additional impact on potential users. Communication message templates are combinations of semantic units with suggested messages that are most likely to motivate consumers to take certain actions.

For practical approval of the use of templates for designing $\mathrm{CM}$ in product promotion to the corporate market, a multi-layered production semantic network has been developed. Network layer multiplicity matches a variety of concepts. Each layer consists of a set of objects that reflect the qualitative composition of the layer. The procedure for selecting variants of communication message templates is a non-cyclic chain of the semantic network using production rules. There are consistently selected elements: the representative of the target audience, the type of consumer behavior, the positioning strategy, the tool for disseminating communication messages, the structural element of communication messages. The results obtained can be useful for directors and managers of small IT companies in organizing Internet advertising of their products.
\end{abstract}

\footnotetext{
${ }^{1}$ The work is conducted under the government assignment of the Ministry of Education and Science of the Russian Federation, project No. 8.8184.2017/8.9
} 
Key words: marketing communications, software product, low-budget advertising techniques, corporate market, communications report, design pattern, semantic network.

Citation: Yekhlakov Y.P., Malakhovskaya E.K. (2018) Design patterns of communication messages for promoting software products on the corporate market. Business Informatics, no. 1 (43), pp. 50-60.

DOI: $10.17323 / 1998-0663.2018 .1 .50 .60$.

\section{Introduction}

T The financial health of any IT company greatly depends on the quality of their advertising activities when promoting their products and/or services. One of the ingredients of success in this matter is an effective marketing communication strategy which not only draws attention of the target audience to the software and communicates its competitive advantages but also encourages its approval and purchase. A key component of communication is a communication message, which should be understood as information disseminated by an advertiser while communicating with potential customers to get their attention and produce a certain type of response. The main challenge of designing communication message content consists in selecting the proper information which will reach a potential customer in a particular form via particular channels and by use of particular instruments [1].

Larger IT companies with bigger budgets hire marketing specialists or specialized agencies to address this issue [2]. At the same time, there are small IT companies (groups of like-minded people, "startups", etc.) on the market which have neither the financial resources nor the marketing expertise to make a quality promotion for their software: self-made ads usually describe the software's functionality, use the language of developers, while they do not communicate the product's competitive advantages to the consumers. Low-budget marketing, an increasingly popular technique, could be one of the promising solutions for this problem [3, 4].

Inline with the aforementioned conditions, this article proposes an approach to organizing lowbudget marketing communications to promote software products to the corporate market. This approach is based on ideas of semiology as one of the key parts of communication theory, methods of artificial intelligence and communication message patterns to promote software products within a field of expertise.

The essentials of semiology as the study of signs and the formation and functionality of sign-systems that can store and communicate information between a "sender" (seller) and a "recipient" as they build their relationship, have been outlined in the works of such scientists as R. Barthes, A.F. Losev, Y.M. Lotman, F. de Saussure among others. The applied aspects of semiotics play a crucial part in forming a communication message and assessing the effectiveness of its impact on recipients; they have been amply described in various works [5-8]. The use of certain syntactic units in the content of a communication message, the semantics and pragmatics of which are matched for given (specific) target groups, allows us "to include the subconscious" of its recipients, all of which significantly increases advertising effectiveness [5].

The concept of a pattern as a tool for construction and development was described for the first time in "A pattern language: Towns, buildings, construction", which outlines the concept of pattern language as "a structured method of describing good design practices within a field of expertise" [9]. Within the scope of the subject field, the main idea of using patterns is not to duplicate thoughtlessly the results of other people's work (advertising texts), but rather to use them to select a type of communication message content that best matches the basic characteristics of the software product for consumers on the corporate market (target audience); it is an essential condition for the effective communication and, as a result, leads to an increase in the 
probability of obtaining positive results by using proven problem-solving methods [10].

The ontology as a methodology for describing the subject field [11] and the mathematical apparatus of production systems [12] are used as a formal apparatus for presenting a model of creating design patterns of communication messages for promoting software products to form an effective communication message out of many variants of semantic units taking into account the special characteristics of the various consumer groups.

\section{Semantic network of creating design patterns for communication messages promoting soft- ware products}

According to the main rules of marketing, the communication message content should reflect the characteristics of consumer preferences of the target audience, as well as of a product and/or service and channels and tools for disseminating information. Moreover, to satisfy the expectations and needs of the target audience, the communication message should present a unique product offering, urge the target audience to perform a certain act and state whether any constraints apply (time, quantity, etc.) [3-5]. The content of a communication message also depends on the elements of its composition: header, beginning, information block, reference information, echophrase (slogan), and format of presentation of the advertising message (news, recommendation, etc.) [13]. Consequently, creating design patterns of communication messages for promoting software products should be based on these provisions.

Given the foregoing and as was done in other works $[14,15]$, we present a model for designing the content of a communication message in the form of a semantic network where the previously identified marketing elements and factors affecting them are denoted by vertices with corresponding concepts and the linkages or associations between them, expressed in a verbal form, are denoted by edges (Figure 1).
"Software" (product) and "consumer" (target audience) are the key concepts of the semantic network. The notion of "software" corresponds to the information about the group to which the promoted software belongs (category, type of software). Each software has certain properties that can be expressed in terms describing its characteristics: price, functionality, quality, delivery options and support, etc. "Consumer" combines the target groups of potential users of software (recipients of the communication message) with similar consumer preferences and similar reaction to the methods used to draw attention to the product. Problems of software product consumers on the corporate market are caused by dissatisfaction either with the existing product or with the current state of business processes. Some target groups are viewed from a marketing standpoint as carriers of "goals", i.e. the desired outcome from the practical use of software. Goals are often attributable to a "problem" that a consumer wants to (can) resolve using the software product.

In the corporate sales market, the role functions in relation to the characteristics of the software identify direct users of the software product, IT specialists responsible for the installation, adaptation and maintenance of the software product, as well as the company's executives [16]. Each group of potential consumers with their specific goals has special consumer preferences (expectations) with respect to software. "Direct users", for example, are interested in the information on the functionality of the advertised software, the possibility of adding extensions, simplicity and clarity of the interface, etc. to be presented in accessible form. IT professionals, in turn, are looking for professional information on software installation services, the software's ability to integrate with other software, the degree of protection from unauthorized access, etc. It is important to communicate to company executives the software price and the possibility of providing discounts, as well as how the software will improve the efficiency of the company's business [16]. 


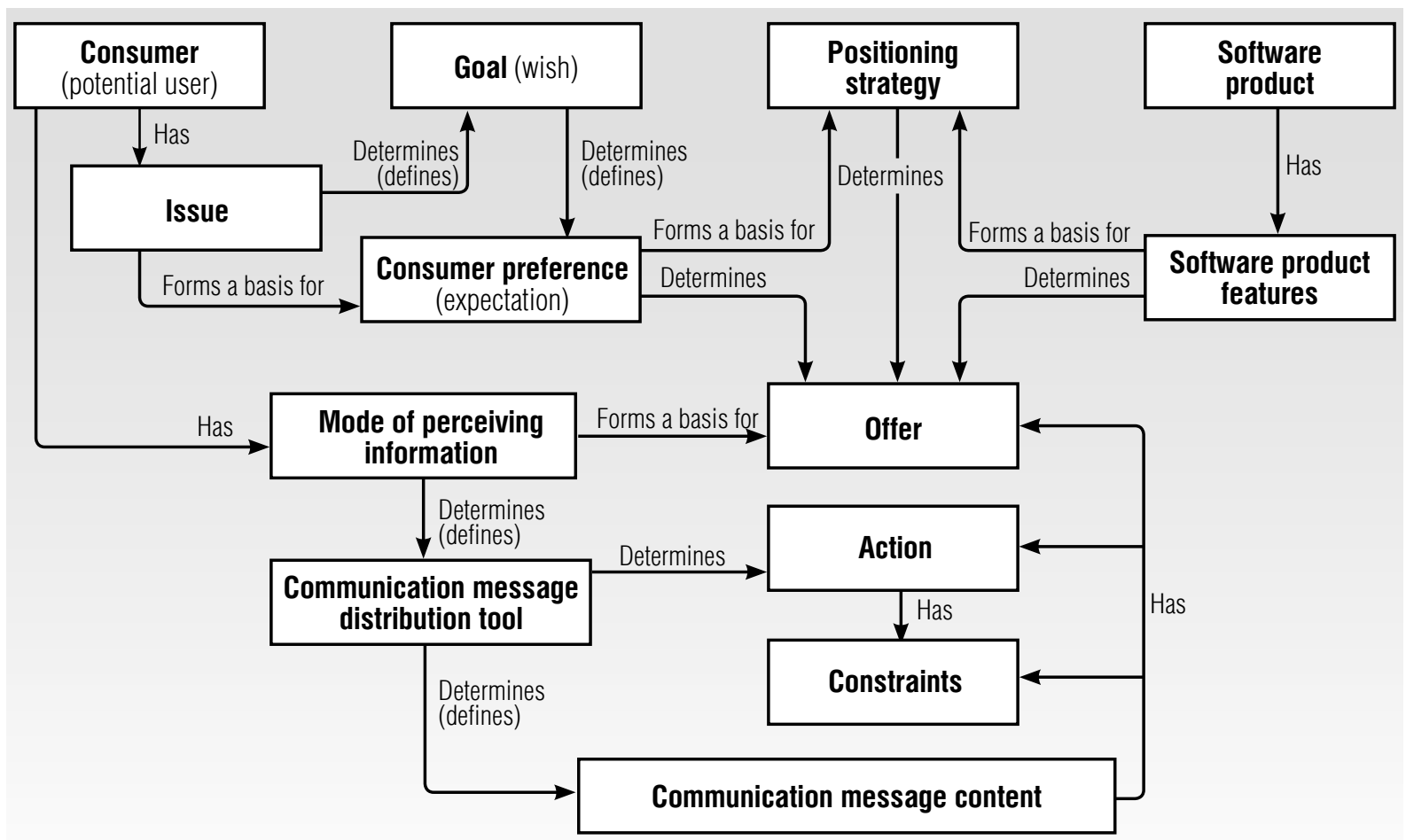

Fig. 1. Semantic network for designing content of a communication message

The software product features that reflect consumer preferences of some target groups form a basis for an "offer". The information that details this concept in the context of the communication message content allows us, on the one hand, to inculcate in minds of a specific group of consumers beneficial and distinguishable properties of the software versus competing products' consumer properties, and on the other hand, aims at solving specific problems and/or achieving the desired result. The description of the offer can be delivered in an interrogative format, a newsletter format, in the form of a recommendation or a solution to a problem, etc.

Representatives of the target groups are distinguished by psychological characteristics that allow us to classify them with one or another type of consumer behavior. For example, the diffusion of innovations theory [17] distinguishes between innovators, pioneers (early adopters), an early majority and later majority (sometimes they are grouped together), and laggards. These types of consumers have different modes of perceiving information, therefore, they are attracted to different characteristics and properties of both the software and communication message, which, of course, should be considered when crafting a promotional communication message and choosing its design, form and format as well as tools for disseminating information.

An important element of the model for creating design patterns of communication messages to promote software products is the "action". It is revealed mostly by the verbs that aim to persuade the reader of a communication message to perform a certain act: "call (right now)", "download" or "buy", "click this button to complete the payment", etc. It is important to note that tools for disseminating communication messages influence the choice of a particular verb: for example, the verb "click" (here) is usually used in banner advertising to take visitors to a "landing page"; in printed brochures, it is more appropriate to urge readers to call or come personally to the company (to get a gift). In addition, the time and place in the description of the action can indicate where and when the potential consumer should act: the organi- 
zation's address or website, time or dates of the promotion, sale, prize-giving, etc. The content of the communication message includes such an element as "constraint", which aims to strengthen the effectiveness of the communication message by stimulating the "consumer" to take an "action" in the near future ("right now", "for only 3 days"). Time ("only for 3 days", "only in December", "from June 1 to June 15", etc.), quantity of product or services ("only to the first three customers", "last three copies at a reduced price", etc.) can serve as a constraint.

The presented semantic network is a conceptual model of the subject field and serves as a basis for creating patterns of communication messages and selecting elements of their content.

\section{Structure and content of design patterns for communication messages}

A set of concept dictionaries of the semantic network forms a basis for creating design patterns of communication messages for promoting software products. The dictionary of each concept includes such elements as objects that determine the concept's composition, a description of the objects' properties, and also semantic units (words, phrases) used to form a communication message and selected to reflect the objects' properties. An example of a description of concept dictionaries used in creating design patterns of communication messages is presented in Table 1 .

Design patterns of communication messages are meant to specify such combinations of semantic units that are most likely to stimulate the target groups of consumers to perform the acts necessary for the seller (advertiser) which will become an indicator of the high advertising effectiveness [18]. To describe the formation of semantic units, we propose to use three types of lexical constructions: target, key, and alternative [19]. Metacharacters are introduced to identify lexical constructions: target lexical constructions are in parentheses, key lexical constructions are in square brackets, alternative lexical constructions are in triangular brackets.

Target lexical constructions describe and define the format of the advertising message in the communication message pattern in the following way: (Sentence: = question, recommendation, solution to a problem, etc.).

Key lexical constructions determine the unique characteristics of concept objects of the "software product" (specific software properties in the categories of price, quality, functionality, etc.) or "consumer" (indicate consumer preferences that should be considered when specifying semantic units). If necessary, the lexical construction can indicate the concept objects (modes of perceiving advertising information) which sets the tone of an appeal to the target audience. Key lexical constructions generally look like this: <Software product features: = price, quality, software functions: Mode of perceiving information: = innovators, early adopters, etc. $>$.

Alternative lexical constructions, based on the modes of perceiving advertising information of representatives of the target audience, are designed to strengthen the influence of semantic units and to exert additional impact on potential users. In general, alternative lexical constructions define a semantic unit of a certain part of speech or a full phrase (word collocation) related to a certain concept object and selected according to the modes of perceiving advertising information by a certain type of user, in a pattern: [Part of speech: = adjective, noun, adverb, participle, phrase, etc.: Concept: = concept objects to which the part of speech refers : Mode of perceiving information: $=$ innovators, early adopters, etc.]. This lexical construction is supposed to provide several variants of semantic units that meet the specified requirements.

In view of the above, a design pattern of a communication message is set by a structured sequence of different combinations of lexical constructions grouped according to the presentation format of the advertising message. Possible variants of the patterns of communication message headings are presented in Table 2.

The sequence, composition, and content of the lexical constructions that form communica- 


\section{Excerpt from concept dictionaries of communication messages' patterns}

\begin{tabular}{|c|c|c|c|}
\hline Concept & $\begin{array}{l}\text { Concept } \\
\text { objects }\end{array}$ & Description of the object property & Semantic units \\
\hline \multirow{2}{*}{ 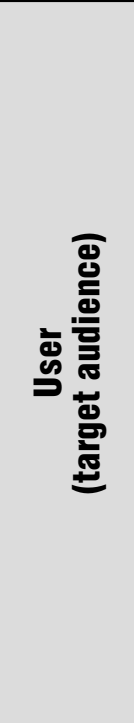 } & Executives & $\begin{array}{l}\text { Interested in: } \\
\text { - strengthening the position of the company on the } \\
\text { market, increasing competitiveness, improving } \\
\text { economic performance; } \\
\text { - growth of business reputation, image and investment } \\
\text { attractiveness of the company; } \\
\text { - the initial cost of the software and the dynamics } \\
\text { of pricing policy during updates; } \\
\text { - operating and maintenance costs for the software. }\end{array}$ & $\begin{array}{l}\text { - "Ensures that your organization } \\
\text { complies with..."; } \\
\text { - "Reduces costs of your organization } \\
\text { and allows..."; } \\
\text { - "Your company will reach a new } \\
\text { level..."; } \\
\text { - "If you plan to become part of } \\
\text { a new... system..."; } \\
\text { - "New standards aimed at... emerge...". }\end{array}$ \\
\hline & $\stackrel{\text { IT }}{\text { specialists }}$ & $\begin{array}{l}\text { Interested in: } \\
\text { - types of software delivery services; } \\
\text { - ease of software installation; } \\
\text { - documentation quality; • operational reliability; } \\
\text { - software's ability to integrate with other software; } \\
\text { - maintenance and technical support; } \\
\text { - protection from unauthorized access; } \\
\text { - recovery time in case of software malfunction } \\
\text { and integrity violation. }\end{array}$ & $\begin{array}{l}\text { - "Reliable"; } \\
\text { - "Characterized by fluid } \\
\text { responsiveness to user requests"; } \\
\text { - "24/7 technical support from our } \\
\text { team". }\end{array}$ \\
\hline \multirow{3}{*}{ 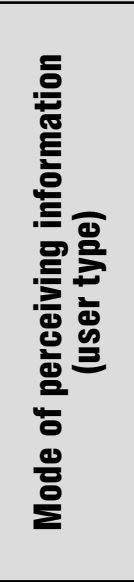 } & Innovators & $\begin{array}{l}\text { Marketing strategy focuses on raising product } \\
\text { awareness. } \\
\text { Focus: new products and services that have } \\
\text { new attributes. } \\
\text { Product life cycle stage: market entry (launch). }\end{array}$ & $\begin{array}{l}\text { - "New"; } \\
\text { - "For the first time"; } \\
\text { - "You've never seen anything like this"; } \\
\text { - "Just for you"; } \\
\text { - "Cutting-edge". }\end{array}$ \\
\hline & $\begin{array}{l}\text { Early } \\
\text { adopters }\end{array}$ & $\begin{array}{l}\text { Marketing strategy: reasoning. } \\
\text { Focus: new products that are already being used } \\
\text { by some consumers. } \\
\text { Product life cycle stage: growth. }\end{array}$ & $\begin{array}{l}\text { - "Trending"; } \\
\text { - "Popular"; } \\
\text { - "The best"; }\end{array}$ \\
\hline & Majority & $\begin{array}{l}\text { Marketing strategy: stimulation. } \\
\text { Focus: reliable, established "classic" goods, } \\
\text { traditional consumer choice. } \\
\text { Product life cycle stage: maturity. }\end{array}$ & $\begin{array}{l}\text { - "Trusted"; • "Quality through ages"; } \\
\text { - "Everyone's favorite"; } \\
\text { - "Already implemented in hundreds } \\
\text { of companies in Russia and abroad"; } \\
\text { • "Approved by professionals". }\end{array}$ \\
\hline \multirow{3}{*}{. } & $\begin{array}{l}\text { Call } \\
\text { to action }\end{array}$ & $\begin{array}{l}\text { A verb (phrase) that urges the reader of } \\
\text { a communication message to perform a certain act. }\end{array}$ & $\begin{array}{l}\text { •"Buy"; } \\
\text { •"Install"; } \quad \text { •Download"; }\end{array}$ \\
\hline & $\begin{array}{c}\text { Place } \\
\text { of action }\end{array}$ & $\begin{array}{l}\text { The place in which (in relation to which) the } \\
\text { specified action should be taken. }\end{array}$ & $\begin{array}{l}\text { - "Address..."; } \\
\text { • "Phone..."; • "Fax...". }\end{array}$ \\
\hline & $\begin{array}{l}\text { Time } \\
\text { of action }\end{array}$ & The time within which an action should be taken. & $\begin{array}{l}\text { •"Business hours..."; } \\
\text { •"Daily"; • "24/7". }\end{array}$ \\
\hline
\end{tabular}

tionmessage patternsanddefinesemanticunitsare determined by subject-matter specialists together with knowledge engineers based on consolidating successful practices of companies' marketing departments and specialized advertising agencies and analyzing advertising texts that were created and published in traditional and electronic media to promote goods and services to the corporate market. The resulting set of communication message patterns grouped according to the format of the advertising message forms the basis of the variants database of communication message patterns allowing marketing experts to select a content pattern for an effective communication message for a specific target group of potential users of software products. 


\section{Excerpt from a presentation of design patterns for communication messages according to the presentation format of the advertising message}

\begin{tabular}{|c|c|c|}
\hline $\begin{array}{l}\text { Presentation } \\
\text { format of the } \\
\text { advertising message }\end{array}$ & $\begin{array}{l}\text { Example of a communication } \\
\text { message pattern }\end{array}$ & $\begin{array}{c}\text { Type of a communication message } \\
\text { pattern(without specifying } \\
\text { the user or software product type) }\end{array}$ \\
\hline \multirow{2}{*}{ Question } & $\begin{array}{l}\text { (Offer: question) [verb : question : consumer] } \\
<\text { software: type }>\text { ? [phrase : price : question] }\end{array}$ & $\begin{array}{l}\text { [Are you searching for, waiting for, looking for, } \\
\text { want, etc.] <type of software>?[Why overpay?] }\end{array}$ \\
\hline & $\begin{array}{l}\text { (Offer: question) [phrase : consumer : issue] } \\
<\text { Consumer: issue }>\text { ? }\end{array}$ & $\begin{array}{l}\text { [You, your organization, your colleagues] } \\
<\text { <ormulation of the consumer's problem }>\text { ? }\end{array}$ \\
\hline News & $\begin{array}{l}\text { [Adjective: software : consumer expectations] } \\
\text { and [Adjective: software : consumer expecta- } \\
\text { tions] <software: type }><\text { software name>. } \\
\text { (Phrase : consumer properties : innovator]. }\end{array}$ & $\begin{array}{l}\text { [High-quality, new, expensive, reliable] and } \\
\text { [High-quality, new, expensive, reliable] <type } \\
\text { of software }><\text { software name }>\text {. [Work beyond } \\
\text { the bounds of the format]. }\end{array}$ \\
\hline
\end{tabular}

\section{Semantic model for selecting variants of communication message patterns}

The process of choosing a variant of the content pattern for a communication message that describes the process of creating the communication message text with the aim of promoting a particular software product to a certain group of consumers, can be presented as a multilayer production semantic network: $G=(X, U)$ where the set of layers $X$ corresponds to the selected concepts of the semantic network. Each layer consists of a set of objects $X i=\{P i j\}$ that reflect the qualitative composition of the layer. The set of directed $U$-graphs reflect the associative relationships between the objects. An excerpt from a description of the layers of the multilayer production semantic network is presented in Table 3.

The associative relations between objects of different layers are represented in the form of adjacency matrices; there are no associative relations between objects of the same layer. An excerpt from an adjacency matrix describing the associative relations between two objects of different layers is presented in Table 4. According to [20], if the software product's life cycle stage is "market entry", the advertising message should be targeted at users who exhibit psychological characteristics and the consumer behavior patterns of the "innovator" type who mainly prefer new products or their updated functionality. In this regard, it is advisable to use such positioning strategies as "Solution to a problem" or "Competitive advantage" to promote the software. The "Solution to a problem" strategy is effective if potential consumers have real problems that they can solve with the help of the product offered, and the consumer has a desire and possibilities to solve them. When using the "Competitive advantage" strategy, it is necessary to focus the consumer's attention on the distinctive features of the software that make it individual and special $[4,5,7,21]$. The choice of a specific strategy should be based on a competitive analysis of a specific software product.

The mechanism of choosing a variant of the content pattern for a communication message lies in forming a non-cyclic chain of the semantic network using a product rule like: $<$ If the object $P 1,1$ is selected in the $S 1$ class, then in the $S 2$ class, the object $P 2,1$ should be selected... and so on $>$. For example, according to the product rule from Table 4, a fragment of a non-cyclic chain will be as follows: <If the object $P 2,1$ is selected in the $S 2$ class, then in the $S 3$ class, the object $P 3,2$ or $P 3,3$ should be selected $>$.

The proposed model is the basic one; the authors admit the possibility of dividing some concepts into smaller parts in the light of experience. Adjustment of the semantic 


\section{Excerpt from a description of the layers of the production semantic network}

\begin{tabular}{|c|c|}
\hline Layer & Layer Objects \\
\hline $\begin{array}{l}S 1-\text { Consumer } \\
\text { target audience }\end{array}$ & $\begin{array}{l}P 1,1 \text { - companies' executives; } \\
P 1,2 \text { - IT professionals; } \\
P 1,3 \text { - users. }\end{array}$ \\
\hline $\begin{array}{l}S 2 \text { - Types } \\
\text { of consumer } \\
\text { behavior }\end{array}$ & $\begin{array}{l}P 2,1 \text { - innovators; } \\
P 2,2 \text { - early adopters; } \\
P 2,3 \text { - majority; } \\
P 2,4 \text { - laggards. }\end{array}$ \\
\hline $\begin{array}{l}\text { S3- } \\
\text { Positioning } \\
\text { strategy }\end{array}$ & $\begin{array}{l}P 3,1 \text { - value; } \\
\text { P3,2 - solution to a problem; } \\
\text { P3,3 - competitive advantage (attribute); } \\
P 3,4 \text { - association; } \\
\text { P3,5 - niche target audience. }\end{array}$ \\
\hline $\begin{array}{l}\text { S4 - Tools for } \\
\text { disseminating } \\
\text { communication } \\
\text { messages }\end{array}$ & $\begin{array}{l}P 4,1 \text { - mailing lists; } \\
P 4,2 \text { - media; } \\
P 4,3 \text { - banner advertisement; } \\
P 4,4 \text { - news sites, reviews; } \\
P 4,5 \text { - contextual advertising. }\end{array}$ \\
\hline $\begin{array}{l}\text { S5 - } \\
\text { Communication } \\
\text { message } \\
\text { elements }\end{array}$ & $\begin{array}{l}\text { P5,1 - header format: news; } \\
\text { P5,2 - header format: question; } \\
\text { P5,3 - header format: recommendation; } \\
\text { P5,4 - header format: solution } \\
\quad \text { to a problem; } \\
\text { P5,5 - header format: niche target } \\
\quad \text { audience. }\end{array}$ \\
\hline $\begin{array}{l}\text { S6- } \\
\text { Communication } \\
\text { message } \\
\text { patterns }\end{array}$ & $\begin{array}{l}\text { This layer contains combinations } \\
\text { of objects of the previous layers and } \\
\text { defines a path to the communication } \\
\text { message patterns. }\end{array}$ \\
\hline
\end{tabular}

model for selecting variants of communication message patterns is carried out in the following way: a basic model is constructed based on the knowledge and experience of the analyst expert in the field of marketing - many concept objects are selected and assigned to certain
Table 3. layers; the logic of constructing associative relationships between objects of different layers is determined. This version of the model allows a marketing specialist in a small IT company to interactively organize their work to continuously select one object from each layer of the production semantic network (Figure 2). Subsequently, as the knowledge base grows, it may become possible to generate automatically variants of patterns according to the request made by a marketing specialist.

Any changes (clarifications) of product rules based on the reaction of the target audience to the generated advertising texts should be implemented based on the experts' analysis of the conversion rate as the number of representatives of the target audience who carried out the desired action (visited the website that contains information about the software, downloaded the trial of the software, made an online purchase of the software, etc.) out of the total number of users who had contact with the communication message, expressed in percentages [18].

\section{An example of generating the content of a communication message}

As an example, let's consider a small IT company that has a completed unique software package - "Generator of working programs" which helps professors to create work programs and funds of evaluation tools that comply with the order № 1367 of the Ministry of Education and Science of the Russian Federation of December 19, 2013. In the context of a limited budget, the IT company management needs

Associative relations between objects of the "Types of consumer behavior" and "Positioning strategy" layers

Table 4.

\begin{tabular}{c|c|c|c|c|c}
\hline \multirow{2}{*}{$\begin{array}{c}\text { Types } \\
\text { of consumer } \\
\text { behavior }(\mathcal{S} 2)\end{array}$} & $\begin{array}{c}\text { Value } \\
(\mathbf{P 3}, 1)\end{array}$ & $\begin{array}{c}\text { Solution to a } \\
\text { problem }(\boldsymbol{P 3}, 2)\end{array}$ & $\begin{array}{c}\text { Competitive } \\
\text { advantage }(\boldsymbol{P 3}, 3)\end{array}$ & $\begin{array}{c}\text { Association } \\
(\mathbf{P 3}, 4)\end{array}$ & $\begin{array}{c}\text { Niche target } \\
\text { audience }(\boldsymbol{P 3}, 5)\end{array}$ \\
\hline Innovators $(P 2,1)$ & - & + & + & - & - \\
\hline
\end{tabular}


to develop a set of marketing measures to promote the software package to the target market segments (to determine the content of the communication message with a focus on preferences of consumers).

To solve this task, during the first stage (Figure 2), the IT company employees selected the head (of the university's management department) who, on the one hand, is responsible for compliance with the educational legislation and, on the other, has the authority to manage the financial resources of the university - as the representative of the target audience from the objects of the "Consumer target audience" layer (Table 3).

The second stage involves determining the type of consumer behavior of the decisionmaker. To do this, the current situation of the software package on the market is analyzed in an interactive way: since the product is only entering the market, it is recommended make an advertising message that targets "innovators".

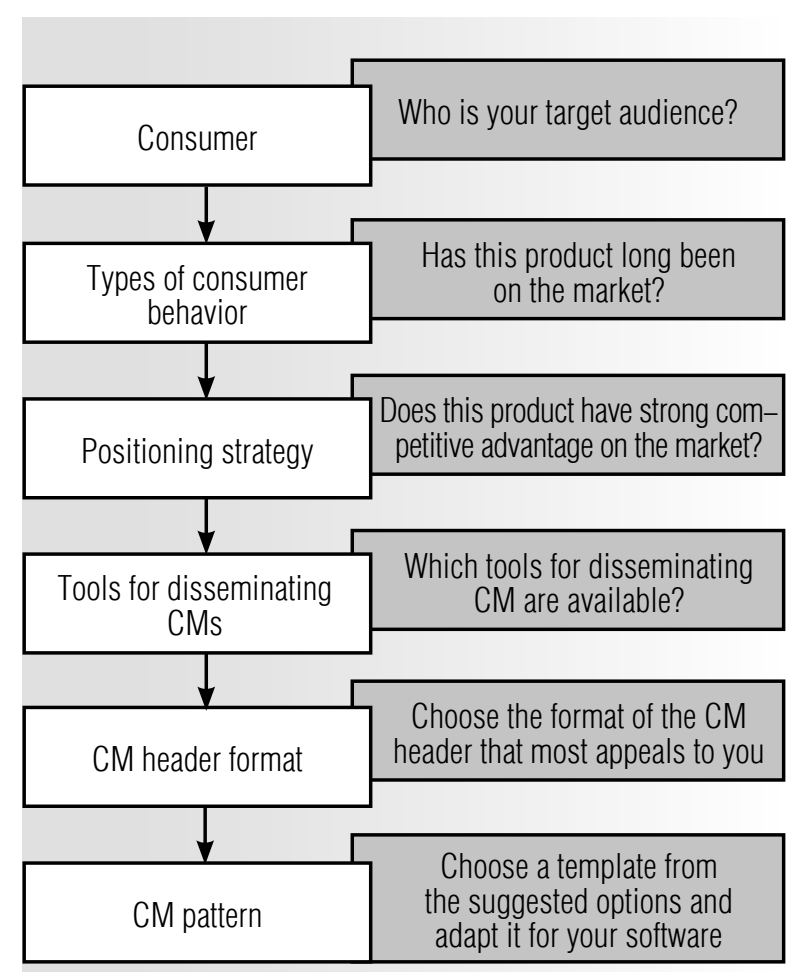

Fig. 2. Excerpt from a dialogue to select variants of design patterns for communication messages
The third stage involves choosing a positioning strategy that can be used to promote the software package. Taking into account the example described in Table 4, it was decided to use the "Solution to a problem" strategy. Based on the provisions of differentiated marketing and with the aim of fully communicating the unique consumer properties of the software package to the executive manager, the "mailing list" (by email) was chosen as the tool for disseminating a communication message. Given the clear problems that university professors face when creating work programs and funds of evaluation tools, "question" was chosen as the header format (Table 2).

Thus, the non-cyclic chain of the semantic network for creating a communication message pattern looks like this: $<P 1,1-$ company's chief executive officers; $P 2,1$ - innovators; $P 3,2-$ solution to a problem; $P 4,1$ - mailing lists; $P 5,1-$ header format: question $>$.

As a result of using the data in Tables 1 and 2, the following variant of the communication message pattern is proposed (the parentheses in the key lexical construction are omitted):

Headline: Do you have a problem with $<$ formulation of the consumer's problem $>$ ?

Beginning: <Software name> will ensure that your organization complies with [legislation, standards, requirements, regulations, expectations]!

Information block: This (cutting-edge, unique, new, innovative) <type of software> will reduce costs of your organization and allow $<3-4$ software key functions $>$. <Software name $>$ from $<$ developer's company name $>$ will become a universal solution to <formulation of the consumer's problem $>$.

Reference information: (Download, install) a free trial of $<$ software name $>$ to $<$ software key function $>$ on $<$ site link $>$. The trial version is valid for $<$ period of validity $>$. You can consult an expert by calling $<$ contact phone number $><$ work schedule $>$.

After giving body to the linguistic constructions, the communication message content may have the following form: 
Do you have problems of compliance with the order № 1367 of the Ministry of Education and Science of the Russian Federation of December 19, 2013? The generator of working programs will ensure that your organization complies with the statutory documents of the Ministry of Education and Science of the Russian Federation; $42 \%$ of all failures of the university to comply with the statutory documents is due to careless drafting of work programs!

This unique generator of working programs will reduce costs of your organization and facilitate and accelerate the process of creating work programs and funds of evaluation tools by professors; automate the process of checking the work program at all stages of approval thereby significantly reducing the time of internal paperwork; track and keep records of the availability of working programs in the university in the context of individual faculties, professors, and disciplines.

The generator of working programs from Tomsk State University of Control Systems and Radioelectronics (TUSUR) will become a universal tool to tackle the monotonous manual labor of your faculty.

Install a free trial of the generator to automatically create work programs on https:// workprogram.tusur.ru/ The trial version is valid for 1 month. You can consult an expert by calling 8 (3822) 70-15-57 at any time.

\section{Conclusion}

The proposed approach as a set of methods based on the provisions of semiology, ideas of communication theories, conceptual modeling and production systems, methods of artificial intelligence and design patterns of communication messages within a field of expertise, is focused on solving an important task (from the authors' point of view) of organizing Internet advertising when marketing low-budget software projects.

The use of positive experience from advertising agencies in the field of online advertising in patterns should help, above all, small IT companies (startups, groups of like-minded developers) to develop text communication messages that contain the semantic units that are most likely to urge their readers to perform desired actions and so increasing advertising effectiveness, in the context of a limited budget.

The issues of economic efficiency, quality of advertising texts, as well as changes in patterns and product rules will be examined by the authors in the future as statistical estimates of advertising effectiveness build up. Conversion rates [18] are to be used as quantitative assessment of efficiency.

The presented semantic network of design patterns for communication messages and the multilayer production semantic network for selecting variants of patterns constitute the basis of the software complex to be developed. The software complex functionality aims, on the one hand, at automating the work of professional knowledge engineers to maintain classifiers of layers and objects, form a semantic network structure, maintain a database of communication message patterns, maintain a rules-based system for selecting patterns, support a query generation language model, build a knowledge base, and on the other hand at creating a UI for marketing specialists (employees of IT companies) for practical purposes of selecting communication message patterns according to the generated queries that characterize the promoted software and/or potential consumers.

\section{References}

1. Yekhlakov Yu.P., Baraksanov D.N. (2012) Osnovnye polozheniya po razrabotke programmy prodvizheniya programmnykh produktov $\mathrm{v}$ seti Internet [The main provisions on the development of the program of promotion of software products in the Internet]. Business Informatics, no. 4 (22), pp. 33-39 (in Russian).

2. Vasiliev R.B., Levochkina G.A. (2012) Otsenka stepeni zrelosti rossiyskogo rynka IT-uslug [Estimation of maturity of the Russian IT services market]. Business Informatics, no. 2 (20), pp. 56-64 (in Russian). 
3. Lewinson J., Hanley P. (2006). Partizanskiy marketing [Guerrilla marketing]. St. Petersburg: Piter (in Russian).

4. Mann I.B. (2009) Bez byudzheta. 57 effektivnykh priemov marketinga [Without a budget. 57 effective marketing techniques]. Moscow: MIF (in Russian).

5. Romat E.V. (2008) Reklama [Advertising]. St. Petersburg, Piter (in Russian).

6. Yelina E.A. (2016) Semiotika reklamy [Semiotics of advertising]. Moscow: Dashkov and Co. (in Russian).

7. Mokshantsev R.I. (2000) Psikhologiya reklamy [Psychology of advertising]. Moscow: INFRA-M; Novosibirsk: Novosibirskoe soglashenie (in Russian).

8. Pirogova Yu.K., Parshin P.B. Reklamnyy tekst: Semiotika i lingvistika [Advertising text: Semiotics and linguistics]. Moscow: Grebennikov Publishing House (in Russian).

9. Alexander C., Ishikawa S., Silverstein M. (1977) A pattern language: Towns, buildings, construction. N.Y.: Oxford University Press.

10. van der Merwe R. (2012) Design patterns: When breaking the rules is OK. Available at: https://www. smashingmagazine.com/2012/06/design-patterns-when-breaking-rules-ok/ (accessed 26 June 2017).

11. Kudryavtsev D.V. (2010) Sistemy upravleniya znaniyami i primenenie ontologiy [Knowledge management systems and application of ontologies]. St. Petersburg: Polytechnic University (in Russian).

12. Gavrilova T.A., Khoroshevskiy V.F. (2000) Bazy znaniy intellektual'nykh sistem [Knowledge bases of intelligent systems]. St. Petersburg, Piter (in Russian).

13. Yekhlakov Yu.P., Baraksanov D.N. (2016) Struktura i soderzhanie kommunikatsionnogo soobshcheniya pri organizatsii Internet-reklamy programmnykh produktov [Structure and content of the communication message in the organization of Internet advertising of software products]. Internet Marketing, no. 3 (93), pp. 146-156 (in Russian).

14. Pronina V.A., Shipilina L.B. (2009) Ispol'zovanie otnosheniy mezhdu atributami dlya postroeniya ontologii predmetnoy oblasti [Application of relations between attributes for constructing a domain ontology]. Problemy Upravleniya, no. 1, pp. 27-32 (in Russian).

15. Temnikova E.A., Aslamova V.S., Berestneva O.G. (2015) Ontologicheskoe modelirovanie predmetnoy oblasti uchrezhdeniya dopolnitel'nogo professional'nogo obrazovaniya [Ontological modeling of the subject area of the institution of additional professional education]. Ontology of Designing, no. 4 (18), pp. 369-386 (in Russian).

16. Yekhlakov Yu.P. (2009) Vyvod prikladnogo programmnogo obespecheniya na rynok korporativnykh prodazh: vzglyad razrabotchika [Output of application software to the corporate sales market: developer's view]. Marketing in Russia and Abroad, no. 4 (72), pp. 45-50 (in Russian).

17. Mikhalyova E.P., Chinilina K.A. (2013) Model' diffuzii potrebitel'skikh innovatsiy na osnove postroeniya kumulyativnoy krivoy [Model of diffusion of consumer innovations based on the construction of a cumulative curve]. Creative Economics, no. 11 (83), pp. 46-53 (in Russian).

18. Memosales.ru (2017) Metody otsenki effektivnosti reklamy [Methods for evaluating the effectiveness of advertising]. Available at: http://memosales.ru/reklama/ocenka-effektivnosti-kampanii (accessed 15 September 2017) (in Russian).

19. Mitrofanova O.A., Panicheva P.V., Lyashevskaya O.N. (2013) Vizualizatsiya dannykh dlya kataloga russkikh leksicheskikh konstruktsiy (na materiale NKRYa) [Visualization of data for the catalog o $\mathrm{f}$ Russian lexical constructions (based on the material of the NKRN)]. Computer Linguistics and Intellectual Technologies, no. 12 (19), pp. 465-477 (in Russian).

20. Powerbranding,ru (2017) Upravlenie tovarom na raznykh stadiyakh ZhTsT [Managing the goods at different stages of the product life cycle]. Available at: http://powerbranding.ru/marketing-strategy/ razvitiye-tovara/ (accessed 15 September 2017) (in Russian).

21. Powerbranding,ru (2017) Unikal'nye sposoby pozitsionirovaniya [Unique methods of positioning]. Available at: http://powerbranding.ru/pozicionirovanie/main-types/ (accessed 15 September 2017) (in Russian). 